\title{
Does Entrepreneurship Education in Family Business Affect Entrepreneurial Attitudes and Motivation?
}

\author{
Muhammad Hasan ${ }^{*}$, Thamrin Tahir1, Nurdiana1, Karuniana Dianta \\ Arfiando Sebayang ${ }^{2}$, Nur Fatwa ${ }^{3}$ \\ ${ }^{1}$ Faculty of Economics and Business, Universitas Negeri Makassar, Indonesia \\ ${ }^{2}$ Faculty of Economics, Universitas Negeri Jakarta, Indonesia \\ 3 School of Strategic and Global Studies, Universitas Indonesia, Indonesia
}

\begin{tabular}{l}
\hline Article Info \\
\hline Article history \\
Received: 29 April 2020 \\
Accepted: 10 October 2021 \\
Published: 11 October 2021 \\
\\
Keywords: \\
Entrepreneurship education; \\
Entrepreneurial attitudes; \\
Entrepreneurial motivation; \\
Family Business; Culinary \\
sector
\end{tabular}

\begin{abstract}
The ability to survive a family business during the COVID-19 pandemic is a very interesting concept to study, because almost every family business has difficulty maintaining its business in the midst of the COVID-19 pandemic, so based on this, this study aims to analyze and reveal the influence of entrepreneurship education in family towards entrepreneurial motivation, either directly, or through mediating the entrepreneurial attitude of family business entrepreneurs in the culinary sector during the COVID-19 pandemic. This study is a non-experimental explanatory study on the culinary sector family business in Makassar City, South Sulawesi. The population in this study is 1,267 family businesses in the culinary sector, with a sample of 133 family businesses in the culinary sector. The findings of this study have succeeded in revealing and exploring that entrepreneurship education in the family has contributed to the formation of entrepreneurial motivation both directly and indirectly through mediating the entrepreneurial attitude of family business entrepreneurs in the culinary sector during the COVID-19 pandemic.
\end{abstract}

\begin{abstract}
Abstrak
$\overline{\text { Kemampuan bertahan bisnis keluarga di masa pandemi COVID-19 }}$ merupakan konsep yang sangat menarik untuk diteliti, karena hampir setiap bisnis keluarga mengalami kesulitan mempertahankan usahanya di tengah Pandemi COVID-19, sehingga berdasarkan hal tersebut, kajian ini bertujuan untuk menganalisis dan mengungkap pengaruh pendidikan kewirausahaan dalam keluarga terhadap motivasi berwirausaha baik secara langsung, maupun melalui mediasi sikap berwirausaha pelaku usaha bisnis keluarga sektor kuliner di masa pandemi COVID-19. Kajian ini merupakan kajian eksplanasi non eksperimen pada bisnis keluarga sektor kuliner di Kota Makassar, Sulawesi Selatan. Populasi dalam kajian ini sebanyak 1.267 bisnis keluarga sektor kuliner, dengan sampel sebanyak 133 bisnis keluarga sektor kuliner. Temuan kajian ini berhasil mengungkap dan mengeksplorasi bahwa pendidikan kewirausahaan dalam keluarga memiliki kontribusi terhadap pembentukan motivasi berwirausaha baik secara langsung, maupun secara tidak langsung melalui mediasi sikap berwirausaha pelaku usaha bisnis keluarga sektor kuliner di masa pandemi COVID-19.
\end{abstract}

\section{How to Cite:}

Hasan, M., Tahir, T., Nurdiana, N., Sebayang, K. D. A., \& Fatwa, N. (2021). Does Entrepreneurship Education in Family Business Affect Entrepreneurial Attitudes and Motivation? Jurnal Pendidikan Ekonomi \& Bisnis, 9(2), 106-118. https://doi.org/10.21009/JPEB.009.2.3

* Corresponding Author. m.hasan@unm.ac.id. Muhammad Hasan 


\section{INTRODUCTION}

COVID-19 pandemic has spread throughout the world and has become a global problem in almost all countries in the world. COVID-19 pandemic not only has a direct impact on public health, but also has an impact on the economy of a country (Juergensen et al., 2020; Kanupriya, 2020). Many economic sectors such as tourism and hospitality, food processing, education, and other economic sectors have been significantly affected by COVID-19 pandemic (Asante \& Mills, 2020; Poudel \& Subedi, 2020; Etemad, 2020).

Empirical facts show that COVID-19 pandemic tends to have an effect on family businesses at the level of micro, small and medium enterprises (MSMEs) (Lim et al., 2020; Cowling et al., 2020; Brown et al., 2020). This is due to the fact that their resources, which include human, financial, and technology, are still very limited compared to family businesses that are at the level of large companies (Martin et al. 2019). However, family businesses at MSMEs level are more flexible and adaptable than family businesses in large companies because of the relatively small size of the business, privately owned, and relatively uncomplicated hierarchical structure, which is very beneficial for family businesses in facing pandemic COVID-19 (Kraus et al., 2020). However, if family businesses experience shocks during COVID-19 pandemic, it will take them longer to return to stable condition after COVID-19 pandemic.

The ability to survive a family business during the COVID-19 pandemic is a very interesting concept to study, because almost every family business has difficulty maintaining its business in the midst of the COVID-19 pandemic, especially family businesses engaged in the culinary sector. With the implementation of various social restriction policies by the government, family businesses in the culinary sector experience various obstacles such as decreased income, changes in consumer behavior, and literacy or knowledge constraints to be able to adapt to changes in the business environment.

The study of family businesses during the COVID-19 pandemic, including the culinary sector family business, is important to do because there are several perspectives. The first perspective is that various strategies are needed by family businesses to maintain the viability of their business. Survival strategy is the ability of all family members to manage the assets and resources they have in the family business in order to maintain the continuity and sustainability of the family business (Beliaeva et al., 2020). The ability and viability of a family business is a series of actions that individuals and households choose in order for them to survive. The ability to survive in the face of economic shocks and pressures during the COVID-19 pandemic is quite important for every family business.

The second perspective is that efforts to survive the COVID-19 pandemic have encouraged many family businesses to immediately provide the right response for their businesses through family business transformation and innovation (Kraus et al., 2020). This is important because the ability of every family business to face and respond to the business environment that occurs during the COVID-19 pandemic is an interesting thing to study. Several previous studies have shown that a family business is a business that looks quite stable and often avoids risks in various changes in the business environment (De Massis et al., 2015), but the COVID-19 pandemic is a situation and condition that is very difficult to avoid by various business people. So based on this perspective, the only way to survive during the COVID-19 pandemic is through innovation.

Based on these two perspectives, the vacancy of studies related to the factors that can make any family business survive during the COVID-19 pandemic is important to do. The phenomenon of family businesses during COVID-19 pandemic is an interesting study to investigate from the entrepreneurial process (Korsgaard et al., 2020). One of the reasons for the failure of family businesses in developing their businesses during COVID-19 pandemic is because family businesses do not have motivation to develop. Several research results indicate various factors that determine the success of the entrepreneurial process. A number of studies focus on the factors that affect entrepreneurship to be carried out, such as personality traits (Murugesan \& Jayavelu, 2017), abilities and experience (Peng et al., 2020), personality and attitudes towards entrepreneurship (Vamvaka et al., 2020), the social environment (Cardella, 2020; Majdouline et al., 2020) and planned 
behavior (Ruiz-Rosa, 2020). Therefore studies on entrepreneurship education, entrepreneurial attitudes, and entrepreneurial motivation during COVID-19 pandemic are important to do.

Based on the factors that determine entrepreneurial success, especially for surviving in COVID-19 pandemic, the ability of a family business to survive in this study will be seen from five aspects namely (1) personality traits; (2) ability and experience; (3) personality and attitudes towards entrepreneurship; (4) social environment; and (5) planned behavior. These five aspects will be studied in terms of the relationship between the three variables which include entrepreneurship education in the family, entrepreneurial motivation, and entrepreneurial attitudes.

The innovation strategy and capability implemented by the family business in order to be able to survive during the COVID-19 pandemic is determined by several aspects, so a study of these aspects is important to do. Based on these two perspectives and supported by several previous studies, the success of entrepreneurs to maintain their business during the COVID-19 pandemic is determined by personality traits, abilities and experience, entrepreneurial personality and attitudes, and social environment, all of which can be studied through the interrelationships between aspects of entrepreneurship education, entrepreneurial attitude, and entrepreneurial motivation during the COVID-19 pandemic. In this regard, this study aims to provide answers to research questions related to the direct and indirect influence of entrepreneurship education in the family on entrepreneurial motivation, through mediating the entrepreneurial attitude of family business actors in the culinary sector. Based on this, it is hoped that the findings of this study can contribute to enriching the literature that examines the relationship between entrepreneurial education in families, entrepreneurial attitudes and motivation as important variables that contribute to the ability of every family business to maintain its business during the COVID-19 pandemic.

Entrepreneurship education in the family will be seen from the knowledge transfer process in the family business which is carried out both nonformally and informally (Hasan et al., 2019; Hasan et al., 2020). During COVID-19 pandemic, entrepreneurship education can contribute to the development of entrepreneurial attitudes as well as abilities and skills, so that it has an impact on self-efficacy and increases motivation to entrepreneurship in a family business (Ratten \& Jones, 2021). During COVID-19 pandemic, knowledge that comes from entrepreneurship education in the family is a significant source of competitive advantage, which enables family businesses to be innovative and remain competitive (Ahmed et al., 2020; Jayakumar \& De Massis, 2020). This knowledge comes from the knowledge transfer process that occurs within each family member in the family business through information that is transformed and developed through personal beliefs, values, education, and experience (Hasan et al., 2020; Bailey \& Breslin, 2021). From a pedagogical perspective, the transfer of knowledge in the perspective of entrepreneurship education is very important for entrepreneurial success because the combination of education and experience is the main factor determining entrepreneurial success.

Based on these facts, it can be seen that entrepreneurship education in the family has a good impact on entrepreneurial attitudes and entrepreneurial motivation during COVID-19 pandemic. Several previous studies have provided support for the influence of entrepreneurship education on entrepreneurial attitudes (Fayolle \& Gailly, 2015; Asitik \& Nunfam, 2019). Attitude is one of the variables used to explain human behavior, including in entrepreneurship research. Attitude is a tendency to respond to things or situations in a way that is in accordance with the object, both the attitude which is liked and the attitude which is not liked. In the Theory of Planned Behavior (Ajzen, 1991), behavior is not formed directly, but begins with intention formed by three components which cover attitudes, subjective norms, and perceptions of behavioral control (Ajzen, 2011). A positive entrepreneurial attitude will not always build positive behavior. This happens because there are control variables that act as obstacles or facilitate the formation of behavior. Facilitative variables that encourage someone to become entrepreneurial are known as behavioral control, explaining that the attitude structure consists of three components namely cognitive, feelings, and tendency to act. Based on this, it can be formulated that entrepreneurship education has a positive and significant influence on entrepreneurial attitudes.

From another perspective, entrepreneurship education also has an impact on 
entrepreneurial motivation, through entrepreneurial attitudes during COVID-19 pandemic. In the Theory of Planned Behavior (Ajzen, 1991), entrepreneurial motivation is determined by his or her own attitude. Several previous studies have attempted to explain the relationship between entrepreneurship education and entrepreneurial motivation. These findings believe that the lack of entrepreneurship education and business competence accounts for the low entrepreneurial motivation, so that it creates significant risks and obstacles to the sustainability of a business and the creation of new businesses (Bae et al., 2014; Barba-Sanchez \& Atienza-Sahuquillo, 2018; Kanama, 2020; Shah et al., 2020). So based on this, it can be formulated that entrepreneurship education has a positive and significant influence directly on entrepreneurial motivation, or indirectly through mediating entrepreneurial attitudes.

Thus, this study will focus on discussing the relationship of entrepreneurship education in the family, entrepreneurial motivation, and entrepreneurial attitudes of family businesses in the culinary sector during COVID-19 pandemic. The family businesses in the culinary sector during COVID-19 pandemic are businesses that are impacted by the imposition of various policies on restricting people's interactions outside homes so that it has an impact on sales operating hours which make businesses in the culinary sector sink. However, the family businesses in the culinary sector still have the potential to survive with the assumption that it emphasizes the adaptation of new normal condition by using online platforms or by opening stalls which implement health protocols. This study provides a different perspective in looking at entrepreneurship education in the family, entrepreneurial motivation, and entrepreneurial attitudes in the family businesses in the culinary sector to be able to survive and even develop during COVID-19 pandemic.

\section{METHOD}

This study used an explanatory research design, which was non-experimental and aimed to examine the effect of entrepreneurship education in families on entrepreneurial motivation mediated by entrepreneurial attitudes in the family businesses in the culinary sector during COVID-19 pandemic. A quantitative approach through parameter testing was used to answer the research hypothesis. The data in this study was collected using a questionnaire.

As an explanatory quantitative study, this study was conducted to explore the relationship between the variables of entrepreneurship education in the family on entrepreneurial motivation mediated by entrepreneurial attitudes in the culinary sector family business during the COVID-19 pandemic, in order to obtain specific details regarding the relationship between these three variables in contribute to the ability of small businesses to survive the COVID-19 pandemic. Through this approach, researchers can reveal the specific relationship between the variables of entrepreneurship education in the family on entrepreneurial motivation mediated by entrepreneurial attitudes in the culinary sector family business during the COVID-19 pandemic, which was previously rarely explored by other researchers. This approach allows the researcher to have a broad understanding of the variables studied.

This research was conducted on family businesses in the culinary sector in Makassar City, which spread over a number of districts. The unit of analysis used in the research sample data was the culinary sector family businesses that have been running for at least 2 generations. The total population in this study was 1,267 family businesses in the culinary sector in Makassar City, while the sample size was carried out with the consideration of data analysis requirements which provided a sample size of at least 5 times the number of indicators used in the measurement. Thus, the sample in this study was 133 sector family businesses in culinary sector in Makassar City and subsequently drawn proportionally according to the distribution (Cooper \& Schindler, 2003).

The variables in this study consisted of entrepreneurship education, entrepreneurial attitudes, and entrepreneurial motivation. The data collected from respondents in this study is primary data collected during the implementation period of data collection starting from December 2020 to March 2021. Primary data collected from respondents in this study was obtained directly by researchers when conducting surveys in the field, namely from perpetrators culinary sector family business. 
The method used in collecting data from respondents in this study is a questionnaire or questionnaire. The questionnaire in this study was used to collect data during the field survey. The questionnaire contains questions related to the variables of entrepreneurship education in the family, entrepreneurial attitudes, and entrepreneurial motivation during the COVID-19 pandemic. The questionnaire developed in this study is a questionnaire that uses impartial and straightforward words so that respondents can understand and answer items quickly. Questionnaire items were adopted and developed from theory and previous research with modifications and developments as needed. All statements in the questionnaire use a Likert scale consisting of five points ranging from 1 (strongly disagree) to 5 (strongly agree).

The instruments used in this study have subsequently been tested for validity and reliability. The instrument validity test was carried out by calculating the correlation between each question and the total score using the Product Moment correlation formula. If $r>0.30$, the statement item from the questionnaire is declared valid (Mohajan, 2017), while to test the reliability of the instrument in this study, the researcher uses the Alpha Cronbach method. If Cronbach's Alpha value $>0.60$, the questionnaire is declared reliable or consistent (Mohajan, 2017).

Entrepreneurship education in families with indicators of optimizing the transfer of tacit knowledge and explicit knowledge consisted of recognizing opportunities, evaluating opportunities, initiating opportunities, and the entrepreneurial organization of the culinary sector family business during COVID-19 pandemic (Amorós et al., 2019; Liguori \& Winkler, 2020), meanwhile the measuring scale used was ordinal scale. Entrepreneurship was seen from the tendency to react positively or negatively to the entrepreneurial process that occurred in the culinary sector family business during COVID-19 pandemic (Ruiz-Rosa et al., 2020), and the measurement scale used was ordinal scale. Entrepreneurial motivation included extrinsic rewards, freedom/ autonomy, intrinsic respect and family security (Ertel, 2021) and the scale used was ordinal.

The data analysis technique used in this study was SEM (Structural Equation Modeling) analysis. The stages of data analysis through the structural equation model in this study refer to the data analysis stages proposed by Kline (2011), the basic steps of structural equation modeling can be represented as shown in the flow chart in Figure 1.

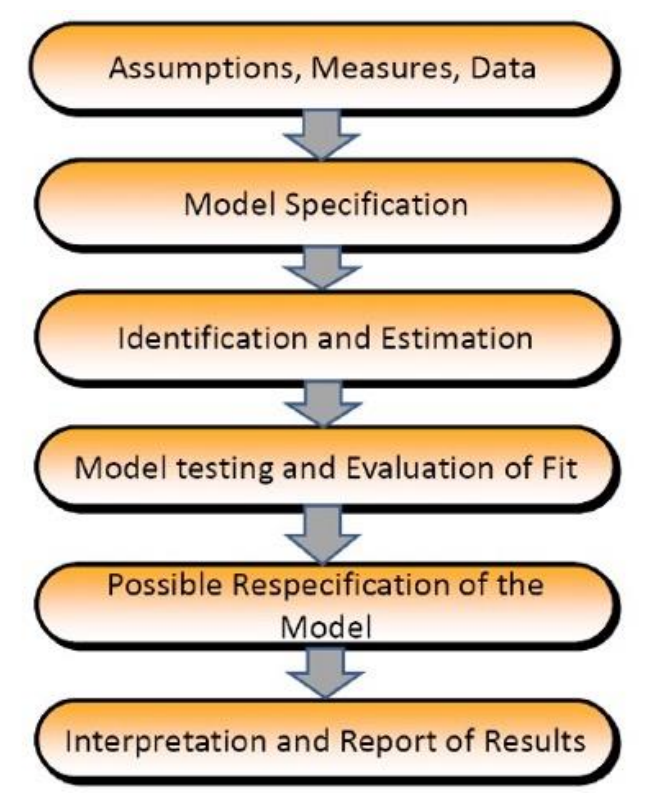

Figure 1. Structural Equation Model Stages

Based on the flow chart of the data analysis stages in Figure 1, it can be seen that after collecting data from the respondents, a number of basic assumptions about sample size, normality, independence, outliers and collinearity were applied. After that, the model is determined, which means that the definition of all causal paths between the variables used in this study must be built 
on some basic theory and theoretical knowledge. Furthermore, identification and estimation of the model are carried out. During model identification, attention should be paid to the many available parameters. Further related to model estimation, an appropriate estimation method should be chosen to achieve successful model verification. The model is then tested and the quality of its fit is evaluated. If the index shows poor fit performance, then modification of the model specification must be made. Then the model is ready to be interpreted correctly.

After the construction of the appropriate CFA model and its affirmative validation, the modeling procedure is continued with the design of the structural model. For this purpose, the appropriate measurement model must be converted to a structural model first. In the next step, the validity of the structural model should be assessed, in which the goodness of fit index and the direction of all paths are investigated, as well as the structural parameters estimated. If the structural model passes the validity test, it can be used to make some conclusions. Otherwise, model refinement is required.

Based on the variables in this study, the research paradigm model related to entrepreneurship education, entrepreneurial attitudes, and entrepreneurial motivation can be seen in the following figure.

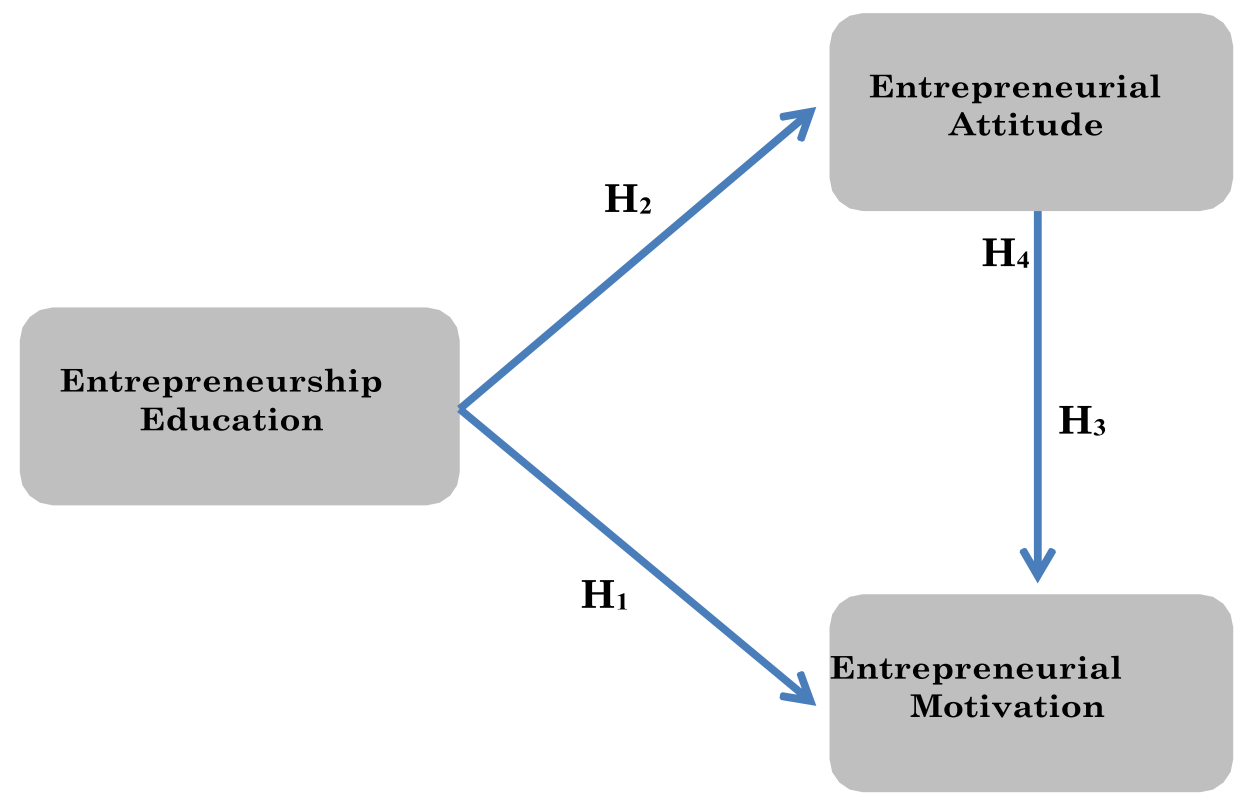

Figure 2. Research Paradigm Model

Based on the research paradigm model supported by theoretical studies, the hypotheses $(\mathrm{H})$ proposed in this study are:

$\mathbf{H}_{1}$ : Entrepreneurship education in the family has a positive and significant influence on the motivation for family business entrepreneurship during the COVID-19 pandemic.

$\mathbf{H}_{2}$ : Entrepreneurship education in the family has a positive and significant influence on the entrepreneurial attitude of the family business during the COVID-19 pandemic.

$\mathbf{H}_{3}$ : The entrepreneurial attitude has a positive and significant influence on the motivation for entrepreneurship in family businesses during the COVID-19 pandemic.

$\mathbf{H}_{4}$ : Entrepreneurship education in the family has a positive and significant influence on entrepreneurial motivation through the entrepreneurial attitude of family businesses during the COVID-19 pandemic. 


\section{RESULTS AND DISCUSSION}

The results of this research and discussion consist of several main parts. The results section will discuss the results of the validity and reliability tests, structural models, and the discussion section will explain more specifically regarding the results that are the findings in this study. In the section on the validity and reliability of the instrument, it will discuss the level of reliability and consistency of the instruments used in this study. Furthermore, the structural model will examine the causal relationship described through structural equation modeling analysis. Finally, the discussion section will try to explore the relationship between the findings of this study and previous studies.

The instrument used in this study has been tested for validity and reliability so that it can be relied on in collecting the data. The results of the validity test of the instrument items for entrepreneurship education variables can be seen in the following table:

Table 1. The Result of the Validity Test of Entrepreneurship Education Instruments

\begin{tabular}{ccc}
\hline No. Item & $\mathrm{r}_{\text {count }}$ & $\mathrm{r}_{\text {table }}$ \\
\hline Items 1.1 & 0.4590 & 0.1703 \\
Items 1.2 & 0.5280 & 0.1703 \\
Items 1.3 & 0.9210 & 0.1703 \\
Items 1.4 & 0.4830 & 0.1703 \\
Items 1.5 & 0.8430 & 0.1703 \\
Items 1.6 & 0.6030 & 0.1703 \\
Items 1.7 & 0.6290 & 0.1703 \\
Items 1.8 & 0.9430 & 0.1703 \\
Items 1.9 & 0.8220 & 0.1703 \\
Items 1.10 & 0.5480 & 0.1703 \\
Items 1.11 & 0.6320 & 0.1703 \\
Items 1.12 & 0.7320 & 0.1703 \\
Items 1.13 & 0.4830 & 0.1703 \\
Items 1.14 & 0.6840 & 0.1703 \\
Items 1.15 & 0.9640 & 0.1703 \\
\hline Source: Data Procs
\end{tabular}

Source: Data Processing Result (2021)

Based on the instrument validity test for the entrepreneurship education variable, it was found that all instrument items were included in the valid category and all items were worthy of being used as the instrument questions. Furthermore, the results of the validity test of the entrepreneurial attitude instrument items were obtained as follows:

Table 2. The Result of the Validity Test of the Entrepreneurial Attitude Instrument

\begin{tabular}{lcl}
\hline No. Item & $\mathrm{r}_{\text {count }}$ & $\mathrm{r}_{\text {table }}$ \\
\hline Items 2.1 & 0.7540 & 0.1703 \\
Items 2.2 & 0.9220 & 0.1703 \\
Items 2.3 & 0.9430 & 0.1703 \\
Items 2.4 & 0.8540 & 0.1703 \\
Items 2.5 & 0.7530 & 0.1703 \\
Items 2.6 & 0.7350 & 0.1703 \\
Items 2.7 & 0.9430 & 0.1703 \\
Items 2.8 & 0.5320 & 0.1703 \\
Items 2.9 & 0.7540 & 0.1703
\end{tabular}




\begin{tabular}{lll} 
Items 2.10 & 0.8320 & 0.1703 \\
Items 2.11 & 0.5430 & 0.1703 \\
Items 2.12 & 0.8320 & 0.1703 \\
Items 2.13 & 0.7350 & 0.1703 \\
Items 2.14 & 0.7320 & 0.1703 \\
Items 2.15 & 0.6730 & 0.1703 \\
\hline
\end{tabular}

Source: Data Processing Result (2021)

The result obtained in the validity test of the entrepreneurial attitude instrument showed that all instrument items were included in the valid category and all items were worthy of being used as instrument questions in this study. Furthermore, the results of testing the validity of the entrepreneurial motivation instrument items were obtained as follows.

\begin{tabular}{ccc} 
Table 3. & \multicolumn{3}{c}{ The Result of Validity Test of Entrepreneurial Motiva } \\
\cline { 2 - 3 } No. Item & $\mathrm{r}_{\text {count }}$ & $\mathrm{r}_{\text {table }}$ \\
\hline Items 3.1 & 0.7230 & 0.1703 \\
Items 3.2 & 0.6320 & 0.1703 \\
Items 3.3 & 0.7640 & 0.1703 \\
Items 3.4 & 0.6430 & 0.1703 \\
Items 3.5 & 0.7340 & 0.1703 \\
Items 3.6 & 0.8430 & 0.1703 \\
Items 3.7 & 0.8640 & 0.1703 \\
Items 3.8 & 0.7340 & 0.1703 \\
Items 3.9 & 0.7540 & 0.1703 \\
Items 3.10 & 0.7430 & 0.1703 \\
Items 3.11 & 0.5340 & 0.1703 \\
Items 3.12 & 0.8260 & 0.1703 \\
Items 3.13 & 0.9460 & 0.1703 \\
Items 3.14 & 0.7260 & 0.1703 \\
Items 3.15 & 0.8410 & 0.1703
\end{tabular}

Source: Data Processing Result (2021)

Based on the validity test of the entrepreneurial motivation instrument, the result showed that all instrument items were categorized as valid and worthy of being used as instrument questions. The next stage was the instrument reliability test. Reliability test was conducted to measure the reliability level of the instrument. The instrument was considered to have a high reliability value if the tests made had consistent results in measuring what was being measured. The reliability of the instrument was analyzed using the Cronbach Alpha coefficient.

The criterion used in the reliability test was if the result of $r$ count has a value equal to or greater than the value of $r$ table ( $r$ count $\geq r$ table) then the instrument was declared reliable. On the other hand, the question item was considered to be unreliable if the result of $r$ count has a value less than the value of $r$ table ( $r$ count $<r$ table). The instrument reliability test was carried out using IBM SPSS version 20. The test result showed that all items for entrepreneurial education variables, entrepreneurial attitudes, and entrepreneurial motivation were in the reliable category.

Table 4. The Summary of Instrument Reliability Test

\begin{tabular}{clc}
\hline No. & \multicolumn{1}{c}{ Variable } & Cronbach's Alpha \\
\hline 1. & Entrepreneurship education & 0.857 \\
3. & Entrepreneurial attitude & 0.892 \\
4. & Entrepreneurial motivation & 0.848 \\
\hline
\end{tabular}

Source: Data Processing Result (2021) 
The alternative model that describes the relationship between the variables of entrepreneurial education, entrepreneurial attitudes, and entrepreneurial motivation in this study, as well as the manifests that constructed them, can be seen in the following figure.

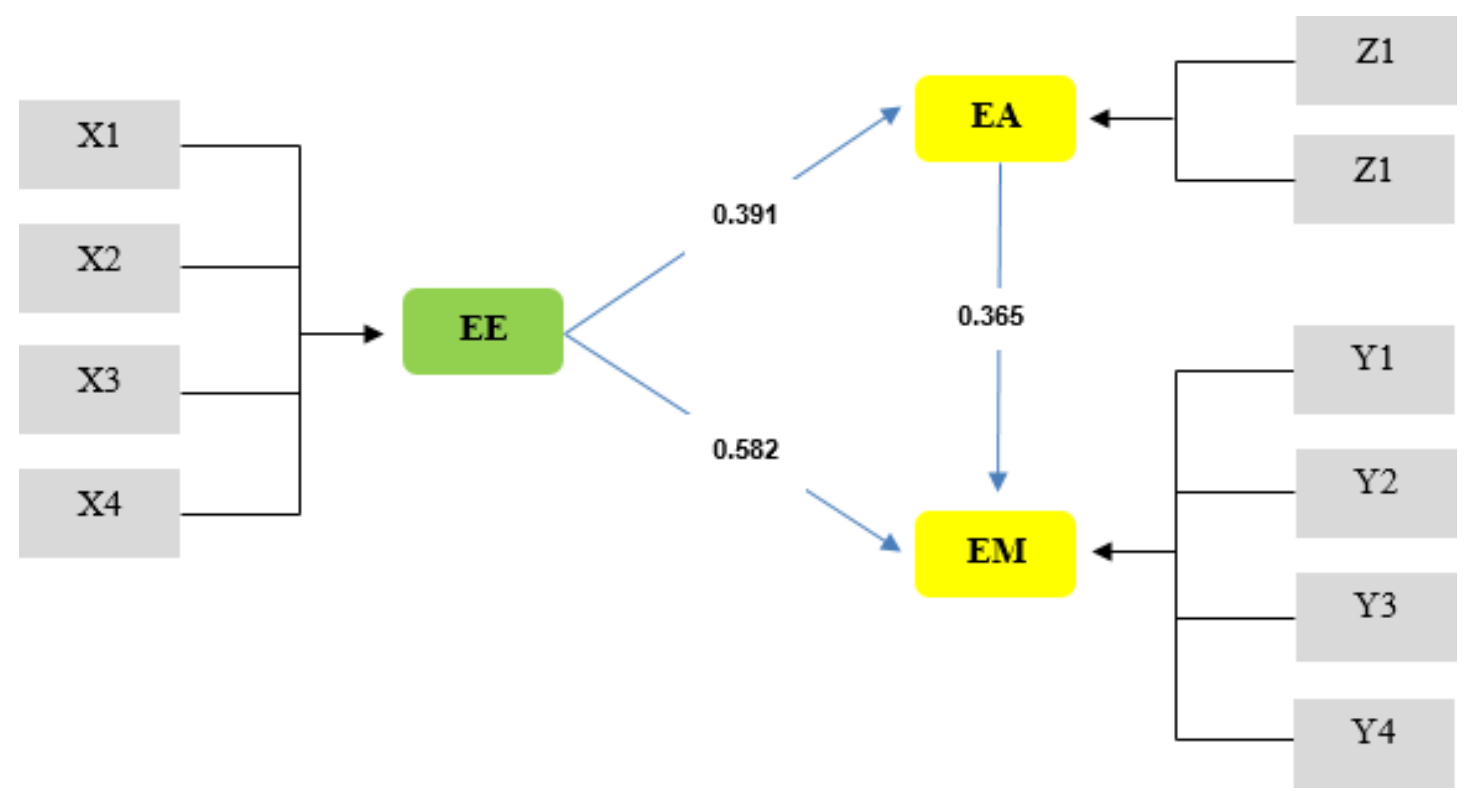

Figure 3. Structural Model Fit

Figure 3 shows a structural model that has met the eligibility criteria, so that based on the results of the study contained in the figure, all of the structural model eligibility criteria have been met.This can be seen from the influence of exogenous variables to endogenous variables which are significant. The fit of the model can also be seen from the value of the coefficient that meets the criteria for the structural model analysis. The results of the fit test for the research structural model can be seen as follows.

Table 5. Structural Model Fit

\begin{tabular}{lcc}
\hline \multicolumn{1}{c}{ Fit Indices } & Coefficient & Criteria \\
\hline Chy-square $\left(\mathrm{X}^{2}\right)$ & 79.67 & Small (nonsignificant) \\
P-Value & 0.613 & $\geq 0.05$ \\
Df & 130 & - \\
Cmin (X'/Df) & 0.954 & $\leq 2.00$ \\
RMR (Standardized) & 0.097 & $\leq 0.08$ \\
RMSEA & 0.00 & $\leq 0.08$ \\
GFI & 0.95 & $\geq 0.90$ \\
AGFI & 0.93 & $\geq 0.90$ \\
CFI & 1.00 & $\geq 0.94$ \\
IFI & 0.99 & $\geq 0.94$ \\
NNFI or TLI & 0.99 & $\geq 0.94$ \\
AIC (Model) & 94.36 & Small, relative \\
\hline
\end{tabular}

Source: Data Processing Result (2021)

All fit levels have met the standard criteria required. The lambda coefficient $(\lambda)$, determination (R2), and T-Value of each manifest variable that construct the variables of entrepreneurial education, entrepreneurial attitudes, and entrepreneurial motivation can be seen in the following table. 
Table 6. The Manifestations of the Structural Model Constructs

\begin{tabular}{|c|c|c|c|c|c|}
\hline No. & Variable & Manifest & $\lambda$ & $\mathrm{R}^{2}$ & T-value \\
\hline \multirow{4}{*}{1} & \multirow{4}{*}{$\mathrm{EE}$} & $\mathrm{X} 1.1$ & 0.64 & 0.05 & 3.50 \\
\hline & & $\mathrm{X} 1.2$ & 0.52 & 0.07 & 3.88 \\
\hline & & $\mathrm{X} 1.3$ & 0.74 & 0.08 & 4.91 \\
\hline & & $\mathrm{X} 1.4$ & 0.82 & 0.05 & 4.96 \\
\hline \multirow{2}{*}{2} & \multirow{2}{*}{ EA } & $\mathrm{Z} 1$ & 0.92 & 0.08 & 3.17 \\
\hline & & $\mathrm{Z} 2$ & 0.53 & 0.06 & 6.86 \\
\hline \multirow{4}{*}{3} & \multirow{4}{*}{ EM } & Y1 & 0.86 & 0.04 & 5.56 \\
\hline & & $\mathrm{Y} 2$ & 0.84 & 0.05 & 5.79 \\
\hline & & Y3 & 0.35 & 0.05 & 6.77 \\
\hline & & Y4 & 0.49 & 0.06 & 7.19 \\
\hline
\end{tabular}

Source: Data Processing Result (2021)

Each manifest that constructs entrepreneurial education variable, entrepreneurial attitude variable, and entrepreneurial motivation variable meet the validity criteria. This can be seen from the standard loading value $(\lambda \geq 0.40)$ and the value of $R 2 \leq \lambda$. The results obtained in the analysis and finding model are tabulated by the coefficient of direct influence between variables as follows.

Table 7. The Conclusion of Data Analysis on Direct and Indirect Effects between Variables

\begin{tabular}{clccccc}
\hline \multirow{2}{*}{ No. } & \multicolumn{1}{c}{ Testing } & \multicolumn{3}{c}{ Coefficient_Effect } & \multirow{2}{*}{ T-Value } & \multirow{2}{*}{ Conclusion } \\
\cline { 3 - 5 } & & Direct & Indirect & Total & & \\
\hline 1 & EE $\rightarrow$ EM & 0.582 & - & 0.582 & 3.59 & Significant \\
2 & EE $\rightarrow$ EA & 0.391 & - & 0.391 & 2.53 & Significant \\
3 & EA $\rightarrow$ EM & 0.365 & - & 0.365 & 2.41 & Significant \\
4 & EE $\rightarrow$ EA $\rightarrow$ EM & - & 0.212 & 0.212 & 2.23 & Significant \\
\hline
\end{tabular}

Source: Data Processing Result (2021)

Entrepreneurship education has a direct and significant effect on the entrepreneurial attitude of family business in the culinary sector during COVID-19 pandemic by 39.1\%. Entrepreneurship education that took place within the family environment can foster entrepreneurial motivation in the family through the transformation of tacit knowledge that came from parents and businessmen themselves and explicit knowledge which was derived from the internet and social media. This transformation of tacit and explicit knowledge builds the ability of businessmen in the family businesses to recognize opportunities, evaluate opportunities, initiating opportunities, and the entrepreneurial organization of the family business in the culinary sector during COVID-19 pandemic. The finding of this study is supported by several previous studies which state that the entrepreneurial attitude of family business is influenced by entrepreneurship education that takes place in the family with the formation of the ability of each family member to maintain and continue the business (Du \& Wang, 2019). Besides that, the entrepreneurial education will shape positive attitude of children or future generations so that they have an interest and desire to continue their business and take risks during COVID-19 pandemic (Motoc, 2020).

In the context of the relationship between entrepreneurship education in the family and entrepreneurial attitude, it leads to an educational process carried out either through conscious or unconscious efforts that takes place in the family through the transfer of knowledge from parents to children or from the previous generation to the next generation in the culinary sector family business. Knowledge transfer in the family business is carried out through a long-term process through mentoring activities, and examples that take place within the family environment to prepare children or the next generation to continue and manage the family business. The findings of other studies that support the findings of this study indicate that entrepreneurship education that takes place in the family is able to produce the next generation who has adequate skills, is responsive to problems, and is able to solve problems properly and rationally, especially to be able 
to survive the COVID-19 pandemic. Entrepreneurship education in the family can be in the form of knowledge and understanding of values, behaviors, and abilities about entrepreneurship in facing life's challenges, including during the COVID-19 pandemic (Berrone \& Gomez-Mejia, 2012; AlOmoush et al., 2020; Firfiray \& Gomez-Mejia, 2021).

In the context of other findings, entrepreneurship education in the family will not be able to form an entrepreneurial attitude if the entrepreneurial education that takes place in the family does not show an entrepreneurial example shown by parents or previous generations because this will actually hinder the growth of entrepreneurial attitudes, especially those related to entrepreneurship awareness of business opportunities (Giritli Nygren \& Olofsson, 2020).

This study also found out that entrepreneurship education has a direct and significant effect on the entrepreneurial motivation of family business in the culinary sector during COVID-19 pandemic by $58.2 \%$. This finding is supported by several previous studies which state that entrepreneurship education has succeeded in providing individuals with the skills to recognize various entrepreneurial opportunities during COVID-19 pandemic (Liguori \& Winkler, 2020). Entrepreneurship education, in relation to the knowledge transfer in the family environment, provides the ability for family members to turn business ideas into reality through creativity, innovation, change in mindset, and motivation to encourage entrepreneurial success.

It was also found out that entrepreneurial attitudes have a direct and significant effect on the entrepreneurial motivation of family business in the culinary sector during COVID-19 pandemic by $36.5 \%$. This finding is in line with several previous studies which also stated that the attitude of an entrepreneur has a significant relationship with entrepreneurial motivation. Other research findings suggest that a person's innovative attitude affects their success in business during COVID19 pandemic because they have high motivation (Ertel, 2021). Other findings show that not only being innovative, but being honest, being creative, having a vision for the future, working seriously, having good planning, and having a good reputation are also positive attitudes that support the creation of entrepreneurial motivation during COVID-19 pandemic (Korsgaard et al., 2020).

The last finding from this study indicates that entrepreneurship education has an effect on entrepreneurial motivation through the entrepreneurial attitude of family business in the culinary sector during COVID-19 pandemic by $21.2 \%$. This finding is in line with several previous findings which show that entrepreneurship education must be started and developed within the family environment (Hasan et al., 2019). The failure and success of the culinary sector family business to survive in COVID-19 pandemic is largely determined by the transfer of knowledge that takes place from previous generations to future generations. Entrepreneurship education can foster awareness of the next generation to have a positive attitude in starting and managing a business, so that in turn this affects the motivation to become entrepreneurs (Hasan et al., 2020).

However, there are several previous studies that are not in line with the findings of this study. Entrepreneurship education in the family can actually increase the entrepreneurial capacity of each next generation in the family business, but if the entrepreneurship education is not able to form knowledge, skills, and attitudes then the motivational aspect will not be formed (Chrisman et al., 2012). Therefore, the main effort is to encourage the development of entrepreneurial motivation in the next generation of family business by providing entrepreneurship education that is able to shape the knowledge, skills, and attitudes and competencies of each family member so that they are able to continue the family business and even create new businesses in the family the time of the COVID-19 pandemic.

The implication of this study is that entrepreneurship education that takes place in the family environment can contribute to shaping entrepreneurial attitudes and motivation through the main effort to provide entrepreneurial education in the family by placing all aspects of resource capacity development in the family to form knowledge, skills, and practical abilities through exemplary processes and long-term practices in family businesses. 


\section{CONCLUSIONS AND SUGGESTION}

The results of this study found that entrepreneurship education has a positive and significant influence, both on entrepreneurial motivation and on the entrepreneurial attitude of the family business in the culinary sector during COVID-19 pandemic, and entrepreneurial attitudes have a positive and significant influence on the motivation to entrepreneurship in the culinary sector family business during COVID-19 pandemic. The results of this study also show that entrepreneurship education has a positive and significant effect on entrepreneurial motivation moderated by the entrepreneurial attitude of the family business in the culinary sector during COVID-19 pandemic.

The findings of this study confirm that entrepreneurship education in the family that can be seen from optimizing the transfer of tacit knowledge and explicit knowledge which cover recognizing opportunities, evaluating opportunities, initiating opportunities, and the entrepreneurial organization of the family business in the culinary sector during COVID-19 pandemic has a positive and significant effect on entrepreneurial attitudes reflected through the tendency to react positively to the entrepreneurial process that occur in the culinary sector family business during COVID-19 Pandemic, and it also has a positive and significant effect on entrepreneurial motivation as seen from extrinsic rewards, freedom/autonomy, intrinsic rewards and family safety, either directly or indirectly. So based on these findings, entrepreneurship education in the family needs to be optimized, especially in creating explicit knowledge, so that it is able to maintain the sustainability of family businesses during COVID-19 pandemic through the growth of positive attitudes in entrepreneurship.

\section{REFERENCES}

Ahmed T., Chandran V. G. R., Klobas J. E., Liñán F., \& Kokkalis P. (2020). Entrepreneurship Education Programmes: How Learning, Inspiration and Resources Affect Intentions for New Venture Creation in a Developing Economy. International Journal of Management in Education, 18(1), 10-32.

Ajzen, I. (1991). Theory of Planned Behavior. Organizational Behavior and Human Decision Processes, 50(2), 179-211.

Al-Omoush, K. S., Simón-Moya, V., \& Sendra-García, J. (2020) The Impact of Social Capital and Collaborative Knowledge Creation on e-Business Proactiveness and Organizational Agility in Responding to the COVID-19 Crisis. Journal of Innovation \& Knowledge, 5(4), 279-288.

Amorós, J. E., Ciravegna, L., Mandakovic, V., \& Stenholm, P. (2019). Necessity or Opportunity? The Effects of State Fragility and Economic Development on Entrepreneurial Efforts. Entrepreneurship Theory and Practice, 43(4), 725-750.

Asante, L. A., \& Mills, R. O. (2020). Exploring the Socio-Economic Impact of COVID-19 Pandemic in Marketplaces in Urban Ghana. Africa Spectrum, 55(2), 170-181.

Asitik, A. J., \& Nunfam, V. F. (2019). Quality and Relevance of Entrepreneurial Education in Ghana: Perspectives of Undergraduate Students. UDS International Journal of Development, 6(3), 41 56.

Bae, T. J., Qian, S., Miao, C., \& Fiet, J. O. (2014). The Relationship Between Entrepreneurship Education and Entrepreneurial Intentions: a Meta-Analytic Review. Entrepreneurship Theory and Practice, 38(2), 217-254.

Bailey, K., \& Breslin, D. (2021). The COVID-19 Pandemic: What can we Learn from Past Research in Organizations and Management? International Journal of Management Reviews, 23(1), 3-6.

Barba-Sanchez, V., \& Atienza-Sahuquillo, C. (2018). Entrepreneurial Intention Among Engineering Students: The Role of Entrepreneurship Education. European Research on Management and Business Economics, 24(1), 53-61.

Beliaeva, T., Shirokova, G., Wales, W., \& Gafforova, E. (2020). Benefiting from Economic Crisis? 
Strategic Orientation Effects, Trade-offs, and Configurations with Resource Availability on SME Performance. International Entrepreneurship and Management Journal, 16(1), 165-194.

Berrone, P., Cruz, C., \& Gomez-Mejia, L. R. (2012). Socioemotional Wealth in Family Firms: Theoretical Dimensions, Assessment Approaches, and Agenda for Future Research. Family Business Review, 25(3), 258-279.

Brown, R., Rocha, A., \& Cowling, M. (2020). Financing Entrepreneurship in Times of Crisis: Exploring the Impact of COVID-19 on the Market for Entrepreneurial Finance in the United Kingdom. International Small Business Journal, 38(5), 380-390.

Cardella, G. M., Hernández-Sánchez, B. R., \& Sánchez García, J. C. (2020). Entrepreneurship and Family Role: A Systematic Review of a Growing Research. Frontiers in Psychology, 10(1), 1-17.

Chrisman, J. J., Chua, J. H., Pearson, A. W., \& Barnett, T. (2012). Family Involvement, Family Influence, and Family-centered Non-economic Goals in Small Firms. Entrepreneurship Theory and Practice, 36(2), 267-293.

Cooper, D. R., \& Schindler, P. S. (2003). Business Research Methods 8th Edition. Boston: McGraw-Hill Irwin.

Cowling, M., Brown, R., \& Rocha, A. (2020). Did You Save Some Cash for a Rainy COVID-19 Day? The Crisis and SMEs. International Small Business Journal, 38(7), 593-604.

De Massis, A., Frattini, F., Pizzurno, E., \& Cassia, L. (2015). Product Innovation in Family versus Nonfamily Firms: An Exploratory Analysis. Journal of Small Business Management, 53(1), 136.

Du, J., \& Wang, R. (2019). Knowledge Transfer and Boundary Conditions: a Study of SMEs in Business Incubation Centers in China. New England Journal of Entrepreneurship, 22(1), 31-57.

Ertel, S. (2021). Small Business Post COVID-19: Motivational Needs through Uncertain Times. Compensation \& Benefits Review, 53(1), 8-15.

Etemad, H. (2020). Managing Uncertain Consequences of a Global Crisis: SMEs Encountering Adversities, Losses, and New Opportunities. Journal of International Entrepreneurship, 18(1), 125-144.

Fayolle, A., \& Gailly, B. (2015). The Impact of Entrepreneurship Education on Entrepreneurial Attitudes and Intention: Hysteresis and Persistence. Journal of Small Business Management, 53(1), 75-93.

Firfiray, S., \& Gomez-Mejia, L. R. (2021). Can Family Firms Nurture Socioemotional Wealth in the Aftermath of COVID-19? Implications for Research and Practice. Business Research Quarterly, 24(3), 249-257.

Giritli Nygren, K., \& Olofsson, A. (2020). Managing the COVID-19 Pandemic through Individual Responsibility: The Consequences of a World Risk Society and Enhanced Ethopolitics. Journal of Risk Research, 23(7-8), 1031-1035.

Hasan, M., Musa, C. I., Arismunandar, Tahir, T., \& Azis, M. (2019). Entrepreneurship Education, Family Capital, and Family Business Performance in Makassar, South Sulawesi, Indonesia. International Journal of Science \& Engineering Development Research, 4(6), 269-272.

Hasan, M., St. Hatidja., Rasyid R., A, Nurjanna, Walenta, A.S., Tahir, J., Haeruddin, M.I.M. (2020). Entrepreneurship Education, Intention, and Self Efficacy: an Examination of Knowledge Transfer Within Family Businesses. Entrepreneurship and Sustainability Issues, 8(1), 526538.

Jayakumar, T., \& De Massis, A. (2020). A Shock to the System: How Family Businesses Can Survive Covid-19. Entrepreneur \& Innovation Exchange, Published online at FamilyBusiness.org.

Juergensen, J., Guimón, J., \& Narula, R. (2020). European SMEs Amidst the COVID-19 Crisis: Assessing Impact and Policy Responses. Journal of Industrial and Business Economics, 47(1), 
499-510.

Kanama, D. (2021). A Comparative Study of the Entrepreneurial Motivation of Undergraduate and Graduate Students in Japan. Industry and Higher Education, 35(2), 102-113.

Kanupriya. (2020). COVID-19: A Socio-economic Perspective. FIIB Business Review, 9(3), 161-166.

Kline, R. B. (2011). Principles and Practice of Structural Equation Modeling, 3rd ed. New York: The Guilford Press.

Korsgaard, S., Hunt, R. A., Townsend, D. M., \& Ingstrup, M. B. (2020). COVID-19 and the Importance of Space in Entrepreneurship Research and Policy. International Small Business Journal, 38(8), 697-710.

Kraus, S., Clauss, T., Breier, M., Gast, J., Zardini, A. and Tiberius, V. (2020). The Economics of COVID19: Initial Empirical Evidence on How Family Firms in Five European Countries Cope with the Corona Crisis. International Journal of Entrepreneurial Behavior \& Research, 26(5), 10671092.

Liguori, E., \& Winkler, C. (2020). From Offline to Online: Challenges and Opportunities for Entrepreneurship Education Following the COVID-19 Pandemic. Entrepreneurship Education and Pedagogy, 3(4), 346-351.

Lim, D. S., Morse, E. A., \& Yu, N. (2020). The Impact of the Global Crisis on the Growth of SMEs: A Resource System Perspective. International Small Business Journal, 38(6), 492-503.

Majdouline, I., El Baz, J., \& Jebli, F. (2020). Entrepreneurship Orientation and Innovation Linkage: The Case of Moroccan Firms. Projectics/Proyéctica/ Projectique, 1(1), 27-45.

Martin, D., Romero, I., \& Wegner, D. (2019). Individual, Organizational, and Institutional Determinants of Formal and Informal Inter-firm Cooperation in SMEs. Journal of Small Business Management, 57(4), 1698-1711.

Mohajan, H. (2017). Two Criteria for Good Measurements in Research: Validity and Reliability. Annals of Spiru Haret University, 17(4), 56-82.

Motoc, A.(2020).Knowledge Dynamics in Family Business. Management Dynamics in the Knowledge Economy, 8(2), 145-157.

Murugesan, R., \& Jayavelu, R. (2017). The Influence of Big Five Personality Traits and Self-efficacy on Entrepreneurial Intention: The Role of Gender. Journal of Entrepreneurship and Innovation in Emerging Economies, 3(1), 41-61.

Peng, H., Zhou, C., \& Liu, Y. (2020). Entrepreneurial Experience and Performance: From the Aspect of Sustainable Growth of Enterprises. Sustainability, 12(1), 1-24.

Poudel, K., \& Subedi, P. (2020). Impact of COVID-19 Pandemic on Socioeconomic and Mental Health Aspects in Nepal. The International Journal of Social Psychiatry, 66(8), 748-755.

Ratten, V., \& Jones, P. (2021). Covid-19 and Entrepreneurship Education: Implications for Advancing Research and Practice. The International Journal of Management Education, 19(1), 100432.

Ruiz-Rosa, I., Gutiérrez-Taño, D., \& García-Rodríguez, F. J. (2020). Social Entrepreneurial Intention and the Impact of COVID-19 Pandemic: A Structural Model. Sustainability, 12(17), 1-17.

Shah, I. A., Amjed, S., \& Jaboob, S. (2020). The Moderating Role of Entrepreneurship Education in Shaping Entrepreneurial Intentions. Jurnal of Economic Structures, 9(1), 1-15.

Vamvaka, V., Stoforos, C., Palaskas, T., Botsaris, C. (2020). Attitude toward Entrepreneurship, Perceived Behavioral Control, and Entrepreneurial Intention: Dimensionality, Structural Relationships, and Gender Differences. Journal of Innovation and Entrepreneurship, 9(1), 126. 